\title{
Printed and Digital Dictionary for Multilingual Literacy Development: A Needs A nalysis
}

\author{
Ni Made Ratminingsih ${ }^{1 *}$, Ketut Agustini², I Gede Budasi ${ }^{3}$, I Ketut Trika Adi \\ $\mathrm{Ana}^{4}$,Ida Ayu Ratsitha Dewi ${ }^{5}$ \\ 1,2,3,4 Universitas Pendidikan Ganesha, Singaraja, Bali, Indonesia \\ ${ }^{5}$ Universitas Pendidikan Nasional, Denpasar, Bali, Indonesia \\ *Corresponding author. Email: made.ratminingsih@undiksha.ac.id
}

\begin{abstract}
This study aimed to describe the needs analysis of the printed and digital dictionary as one of the necessary resources for developing multilingual literacy in primary education. The study applied mixed-method research with a sequential embedded design. In this study, 27 teachers and 656 students from 9 public primary schools of 9 sub-districts of Buleleng regency were involved. The questionnaires and interviews proved that both teachers and students found it necessary to master vocabulary to develop literacy. They also agreed on the importance of multilingual dictionaries, printed and digital, provided with colorful pictures to help students to learn easier. Digital dictionaries were considered more flexible, not torn, and lost. However, the observation of the libraries and teacher rooms proved that the facilities and resources are lacking in most schools. Even there were no multilingual dictionaries in English, Indonesian, and Balinese. Hence, it is recommended for further research to develop the required dictionaries. Next, teachers and students need to regularly use the dictionaries in their teaching and learning process to develop students' multilingual literacy.
\end{abstract}

Keywords: dictionary, literacy development, multilingual, needs analysis, printed and digital.

\section{INTRODUCTION}

One of the required 21-century skills is literacy. Literacy concerns with the ability to read and write. The facts proved that the literacy rate of Indonesian children is very low in Southeast Asia. Their literacy skills viewed from the reading test of Programme for International Student Assessment (PISA) is ranked 64 out of 70 countries with an average of 397 in 2015 [1], [2]. Moreover, this capability continues to decline with an average of 371 (2018) below the average of 487 set by the OECD [3]. These data indicate that literacy skills, especially reading, need serious handling.

Low literacy skills are caused by many factors, such as low quality of education, insufficient infrastructure that supports education (computers, electricity, gadgets, signals, learning media, complete libraries, and books, etc.), as well as students' low reading interest [4]. A recent study proved that the students were rarely or even never told stories by their parents in their childhood. As a result, they were lazy and unmotivated to read. They read only one book for the last two months and spent more time with gadgets than reading. The study concluded that Indonesian students' reading literacy was still unsatisfactory [5].

Reading is one of the skills that form the foundation of literacy. Without good reading competence, students' language literacy skills will also be poor [6], [7]. Therefore, literacy becomes important for language learners because, with good literacy skills, they can understand, create, and communicate information in the form of oral, written, and digital information [8]. The more they read, the better their academic achievement and understanding of their reading and writing [9], [10]. Furthermore, literacy is a crucial factor influencing intellectual and emotional development [11], [12] and for a better quality of future human resources [5]. Thus, it is crucial to develop literacy from an early age, which 
is not only for improving academic achievement but also, more importantly, for intellectual and emotional development to develop a better quality of human resources.

Previous research has proven that dictionaries improve reading comprehension and English vocabulary [13]. The use of dictionaries improves the ability to make English sentences [9]. Furthermore, the reading comprehension of the dictionary user group was significantly higher than the non-dictionary group [12]. The use of both electronic and non-electronic dictionaries and reading strategies were shown to improve reading comprehension [14]. There is a significant difference between the use of printed dictionaries and electronic dictionaries in understanding reading texts and vocabulary, which are the foundations of literacy [15]. So, dictionaries play a central role in improving literacy, both printed and digital dictionaries.

Globalization has increased the value of multilingualism, and speaking different languages has an added value [16]. It is the ability of societies, institutions, groups, and individuals to engage, regularly, with more than one language in their day-today lives [17]. It is a concept that refers to master multiple languages and also implies being raised in diverse social and cultural contexts [18]. Regarding those definitions, multilingualism is the use of more than one language by societies, institutions, groups, and individuals. Considering this, Indonesia has embraced multilingualism in education since its independence in 1945. This is because the Indonesian language, which is the first or second language of Indonesian people, is learned as one subject in the school curriculum and is also used as the medium of instruction. The local languages (mother tongues of most students) are also learned as the local content subjects and as the medium of communication in their daily life in the schools or outsides, depending on the places where they are used because a different place has a different local language. Meanwhile, English is the first and most important foreign language which enters the school curriculum since the primary level of education. This indicates that at least three languages are learned in most schools in Indonesia. Therefore, this research focuses on the needs analysis of the importance of a learning resource, in this case, printed and digital dictionaries, in developing students' multilingual literacy.

\section{LITERATURE REVIEW}

\subsection{Multilingual Dictionary in Language Teaching}

Some recent studies indicate that teaching and learning in more than one language have many positive effects on the learner [19]. Using more than one language has many advantages and is very likely to enhance creativity [20]. Another recent study of the use of more than one language in education proposes prioritizing students' first language, at least during the first six years of school, giving them a strong foundation for learning further languages from secondary education onwards [19]. Considering the results of previous research, multilingual dictionaries can develop primary school students' literacy in three different languages. To enhance their literacy in English, the use of their first and second language, Balinese and Indonesian, is also preserved and developed.

The sources of reading in this digital era are not only printed but also digital. The number of internet users is increasing from time to time. It increased $9.1 \%$ from January 2018 to January 2019. In Indonesia, particularly it increased 13\% in 2018 [21]. This data shows that both sources of learning, printed and digital, are necessary to develop literacy. One of the sources to do so is a dictionary. A dictionary contains words from a language, usually arranged alphabetically, with explanations for their meaning, pronunciation, and spelling. An ideal dictionary should also provide information about word fragmentation, information about the origin of the word, information about the standard or not of a word, information about archaic and classical words, information about the area of use of the word, information about the status of a word, and various other information [22]. There are several types of dictionaries, namely monolingual, bilingual, and multilingual. Monolingual dictionaries are written in one language, while bilingual and multilingual dictionaries contain two or more languages that provide word definitions in a way that is easy to understand and use for bilingual or multi-way language [22], [23]. Various types of dictionaries, which have recently become an attraction for research in the development of reading and writing skills, are printed dictionaries, electronic dictionaries, one-language dictionaries, and two-language dictionaries [15].

For students who are not yet fully covered by technology, learning resources in a printed version of the dictionary provides maximum access to both in-class and outside-of-class learning. In contrast, the digital version can be utilized optimally by those who have had maximum access. The printed dictionaries are still needed, but digital dictionaries are easy and more flexible [24]. The use of technology in learning, such as through mobile phones, allows students to learn inside or outside the classroom [25]. Digital media can replace printed media because it is more flexible, effective, and efficient to use. Digital media is a combination of text, audio, images, or numbers that can be processed on a computer [26]. It can be concluded that technology integration can provide flexibility, efficiency, and 
learning safety, especially during the Covid-19 pandemic.

\subsection{Needs Analysis}

Needs analysis refers to collecting data about students' needs that would be used to develop curriculum, designing tests, compiling materials, teaching activities, and evaluating strategies that meet the needs of a particular group of learners [27], [28]. It has an important role in language learning, whether for specific or general purposes, to bring more relevant programs based on students' needs [29]. It is divided into two, target situation and learning needs. Target situation refers to what students need to do in a target situation, including necessities, lacks, and wants. Meanwhile, learning needs refer to the students' knowledge to perform the required degree of competencies in the target situation [30].

\section{METHOD}

This study applied a mixed-method that integrated both quantitative and qualitative [31]. This research was conducted using a sequential embedded design. The design was sequential because the data was obtained sequentially through questionnaires, interviews, and observations. There were two ways to collect the data. The first was to obtain the primary data from the questionnaires, and the second was to get the supporting data from the interview and observation. Thus, the quantitative data was the primary source, while the qualitative data was used to support the result of quantitative data.
The study subjects were 27 teachers who teach English subjects and 656 students from grades 4, 5, and 6 of elementary schools in 9 districts in Buleleng Regency. They came from 9 elementary schools, which were purposively determined based on the recommendation of the educational supervisor in every sub-district in the Buleleng regency.

There were three instruments used to collect the data, namely questionnaire, interview guide, and observation sheet, which were all have been validated by two experts in the field before it was used to collect data. The results of content validity proved that those three instruments reached a 1.0 score, which means that the instruments had very high content validity to be readily used to obtain the data.

The findings were further analyzed descriptively. First, the results from the questionnaires and observation were presented quantitatively by calculating the percentage. Meanwhile, the results from the interview and observation were described more qualitatively.

\section{FINDING AND DISCUSSION}

The data from the needs analysis collected through the distribution of questionnaires and interviews to teachers and students and the results of observations, are described as follows.

From the questionnaire results distributed to the teachers who teach English subjects in 9 elementary schools in Buleleng Regency, 27 teachers answered the questionnaire. They were teachers who teach in grades 4 , grade 5 , and grade 6.

Table 1. Results of Questionnaires to Teachers in 9 Elementary Schools in Buleleng Regency

\begin{tabular}{|c|c|c|c|}
\hline \multirow[t]{2}{*}{ No } & \multirow{2}{*}{ List of Questions for Teachers } & \multicolumn{2}{|c|}{ Respondent (\%) } \\
\hline & & Yes & No \\
\hline 1 & $\begin{array}{l}\text { Is English taught to students in grades } 4,5,6 \text { of elementary school at the school } \\
\text { where you teach? }\end{array}$ & $25(93 \%)$ & $2(7 \%)$ \\
\hline 2 & $\begin{array}{l}\text { Do you think it is important to teach English to grade 4, 5, } 6 \text { elementary school } \\
\text { students? }\end{array}$ & $27(100 \%)$ & $0(0 \%)$ \\
\hline 3 & Is there a special tutor for English lessons at your school? & $11(41 \%)$ & $16(59 \%)$ \\
\hline 4 & $\begin{array}{l}\text { Do you have adequate teaching materials in teaching English for grade 4, 5, } 6 \\
\text { elementary school students }\end{array}$ & $20(74 \%)$ & 7 (26\%) \\
\hline 5 & $\begin{array}{l}\text { Are the facilities/resources available at the school where you teach adequate to } \\
\text { teach English to grade 4,5, } 6 \text { elementary school students? }\end{array}$ & $16(59 \%)$ & $11(41 \%)$ \\
\hline 6 & Is it important to teach English vocabulary to 4th, 5th, 6th graders? & $27(100 \%)$ & $0(0 \%)$ \\
\hline 7 & Do you use a dictionary in teaching English in class? & $23(85 \%)$ & $4(15 \%)$ \\
\hline 8 & Do you ask students to bring a dictionary to learn English in class? & 23 (85\%) & $4(15 \%)$ \\
\hline
\end{tabular}




\begin{tabular}{|c|l|c|c|}
\hline 9 & $\begin{array}{l}\text { Do you think that using a dictionary is necessary for teaching English vocabulary } \\
\text { to elementary school students? }\end{array}$ & $27(100 \%)$ & $0(0 \%)$ \\
\hline 10 & If a picture dictionary is provided, will you use it in teaching English? & $27(100 \%)$ & $0(0 \%)$ \\
\hline 11 & $\begin{array}{l}\text { If a dictionary in three languages is provided (English, Indonesian, Balinese), will } \\
\text { you use it in teaching English? }\end{array}$ & $25(93 \%)$ & $2(7 \%)$ \\
\hline 12 & $\begin{array}{l}\text { If a digital version of the dictionary is provided, will you use it in teaching } \\
\text { English? }\end{array}$ & $26(96 \%)$ & $1(4 \%)$ \\
\hline
\end{tabular}

Based on Table 1, it can be concluded that teachers considered English lessons important to be given in elementary schools. It is shown from questionnaire items no 1 and 2 that 25 teachers (93\%) teach English in their schools, and all teachers $(100 \%)$ affirmed that English is important to be taught since elementary school (grades 4, 5, 6). However, the facts proved that only 11 teachers $(41 \%)$ stated that English teachers were available in their schools, and the remaining 16 teachers $(59 \%)$ stated that there were no special English teachers. So, the teachers who teach English are mostly classroom teachers. Furthermore, in item 6, all teachers (100\%) emphasized the importance of learning vocabulary in English lessons. This finding follows [13], [15] that vocabulary is the foundation of literacy, and literacy can also develop learners' vocabulary.

Judging from the existing teaching materials, 20 teachers $(73 \%)$ stated that they had adequate teaching materials, but seven teachers $(26 \%)$ stated that they did not have them. Furthermore, in terms of learning facilities/resources, 16 teachers $(59 \%)$ stated that the media/resources were available, while 11 teachers $(41 \%)$ explained that there were insufficient supporting facilities/resources. This evidence confirmed that teachers still needed assistance, both teaching materials, and facilities, or adequate learning resources to carry out learning. When asked about the use of dictionaries, 23 teachers $(85 \%)$ stated that they used dictionaries in class, and they also asked their students to bring dictionaries. So, the majority of teachers considered that the dictionary is important in learning. All teachers (100\%) emphasized that dictionaries are needed in vocabulary learning. If they were provided with picture dictionaries, all teachers agreed $(100 \%)$ to use them, and if a multilingual dictionary was provided, 25 teachers $(93 \%)$ stated that they would use the dictionary in teaching. Furthermore, when asked about the digital version of the dictionary, 26 teachers $(96 \%)$ also stated their willingness to use the dictionary. These findings proved that teachers realized the importance of dictionaries, both printed and digital versions, to develop the students' vocabulary, which strongly supported previous researches [9], [12]-[15].

Table 2. Results of Questionnaires to Students in 9 Elementary Schools in Buleleng Regency

\begin{tabular}{|c|l|c|c|}
\hline \multirow{2}{*}{ No List of Questions for Students } & \multicolumn{2}{|c|}{ Respondent (\%) } \\
\cline { 3 - 4 } & & Yes & No \\
\hline 1 & I feel English is important to learn in elementary school. & $638(97 \%)$ & $18(3 \%)$ \\
\hline 2 & I feel it is important to master a lot of English vocabulary. & $596(91 \%)$ & $60(9 \%)$ \\
\hline 3 & It is important for teachers to teach English vocabulary & $638(97 \%)$ & $18(3 \%)$ \\
\hline 4 & $\begin{array}{l}\text { It is important for teachers to teach English vocabulary bygiving } \\
\text { their meanings into Indonesian or Balinese so that } \\
\text { they are easy to understand. }\end{array}$ & $642(98 \%)$ & $14(2 \%)$ \\
\hline 5 & I use textbooks in learning English in the classroom. & & $127(19 \%)$ \\
\hline 6 & I use student worksheets (LKS) in learning English. & $529(81 \%)$ & $246(38 \%)$ \\
\hline 7 & I use a dictionary in learning English. & $510(62 \%)$ & $122(19 \%)$ \\
\hline 8 & I use the handout provided by the teacher to learn English & $534(81 \%)$ & $131(20 \%)$ \\
\hline 9 & in the classroom. & $525(80 \%)$ & $93(14 \%)$ \\
\hline 10 & I use assignments given to learn English in class. & $563(86 \%)$ & $31(5 \%)$ \\
\hline 11 & I like dictionaries with colorful pictures for learning English. & $597(91 \%)$ & $59(9 \%)$ \\
\hline 12 & I like dictionaries that explain meaning in three languages & $622(95 \%)$ & $34(5 \%)$ \\
\hline
\end{tabular}




\begin{tabular}{|c|l|c|c|}
\hline & (English, Indonesian, Balinese). & & \\
\hline 13 & $\begin{array}{l}\text { I like digital dictionaries that can be operated with a } \\
\text { cellphone or computer. }\end{array}$ & $556(85 \%)$ & $100(15 \%)$ \\
\hline
\end{tabular}

From Table 2, it can be explained that in terms of needs, almost all students (97\%) emphasized the importance of English, especially vocabulary (91\%). Students also stated that teachers need to teach them vocabulary (97\%) and provide meaning in Indonesian or Balinese to make it easy to understand (98\%). Regarding teaching materials or resources, students stated that teachers used textbooks $(81 \%)$, used worksheets $(62 \%)$, used dictionaries $(81 \%)$, used handouts $(80 \%)$, and used assignments $(86 \%)$. Based on this fact, it can be emphasized that teachers have used various teaching materials in teaching, one of which is a dictionary. Furthermore, when asked about their expectations regarding what is needed, the majority of students (95\%) stated that they needed a dictionary in learning English. They also (91\%) emphasized that they like dictionaries with colorful pictures. Furthermore, they stated (95\%) liked dictionaries that provide explanations in three languages and they $(85 \%)$ preferred a digital dictionary that is operated with a cellphone or computer.

From the data above, it can be concluded that both teachers and students shared the same opinions that English needs to be taught since elementary school and that vocabulary is indeed very important. One of the teaching materials or resources that are perceived to be very important is a dictionary. Students stated that they liked dictionaries with colorful pictures and explanations of meaning in three languages, and they also liked digital dictionaries. The teacher also confirmed that they would use both printed and digital dictionaries when equipped with them.

Furthermore, the results of interviews related to the use of dictionaries, both teachers and students gave their explanation described as follows.

T.4: "Yes, make them get accustomed to using dictionaries in class. Most students bring a dictionary. The teacher does not force them to bring. The reason is that students can increase their vocabulary, there is also a way of reading, and students can find difficult words. I don't require it, but sometimes students take the initiative to bring their dictionary."

S.3: "Yes, I have. I bring my dictionary from home. For teachers in class, I don't remember using them, only textbooks or writings on the board. My dictionary only consists of 2 languages, English and Indonesian."

S.4: "I really need a dictionary to add vocabulary. In addition, the knowledge is more from the vocabulary. If I use a dictionary, I can look up what vocabulary the teacher asks for, such as transportation, fruits, etc., so it's easier."

From the above excerpts, it is obvious that both teachers and students affirmed that dictionaries are very important for the students to learn English vocabulary, even they felt that the knowledge of words increased when they know lots of words. In terms of kinds of dictionaries, the findings are as follows.

T.6: "I totally agree that there is a picture dictionary. Especially for elementary school children because they have high imagination power, they will be more interested and understand by looking at pictures. By looking, they can analyze directly. Then, multilingual, yes, I am very supportive, good. The developers' idea is great, because many children can speak Balinese but don't understand Indonesian and English and vice versa so that in the future the children can get to know the three languages better. Likewise, with a digital dictionary, it would be great if it could be digitized, it would be accessible from anywhere, and there would be a way to pronounce it."

S.5: "If there are pictures, I feel more comfortable studying because there are pictures that can guide, attract, and be more enthusiastic in learning. Added with the use of three languages, I am more able to learn three languages properly and correctly. I have a better understanding because every day, I also use Balinese. As for the digital dictionary itself, I agree because it's easier. If it's on a cellphone, it can't be torn and lost."

In terms of kinds of dictionaries, both teachers and students give their similar responses on the importance of dictionaries with colorful pictures, dictionaries that use three languages [16]-[18]. If there are the digital ones, they also felt that learning can be more flexible and can be accessed anywhere, and they will be more interesting because they are equipped with the pronunciations [24]-[26]. The findings also support the previous findings that vocabulary played an important role in students to master English [13], [15]. They could develop it when they had dictionaries, either printed or digital ones [9], [12]-[15]. 
Table 3. The Result from the Observation of the Library/Teacher Room

\begin{tabular}{|c|c|c|c|c|c|c|c|c|c|c|c|c|}
\hline \multirow[t]{3}{*}{ No } & \multirow{3}{*}{$\begin{array}{l}\text { Library/ teacher } \\
\text { room }\end{array}$} & \multicolumn{9}{|c|}{ SDN } & \multirow[t]{3}{*}{ Total } & \multirow[t]{3}{*}{$\%$} \\
\hline & & 1 & 1 & 1 & 1 & 3 & $1 \mathrm{Sk}$ & $5 \mathrm{Sn}$ & $1 \mathrm{~Kb}$ & 2 & & \\
\hline & & $\mathrm{Bj}$ & $\mathrm{Sr}$ & Bs & CB & $\mathrm{BjJ}$ & & & & $\mathrm{Pc}$ & & \\
\hline \multirow[t]{2}{*}{1} & Bilingual & $\sqrt{ }$ & $\sqrt{ }$ & $\sqrt{ }$ & $\sqrt{ }$ & $\sqrt{ }$ & $\sqrt{ }$ & $\sqrt{ }$ & - & - & 7 & 77.7 \\
\hline & Dictionary & & & & & & & & & & & \\
\hline \multirow[t]{2}{*}{2} & Multilingual & - & - & - & - & - & - & $\sqrt{ }$ & - & - & 1 & 1.1 \\
\hline & Dictionary & & & & & & & & & & & \\
\hline \multirow[t]{2}{*}{3} & $\begin{array}{l}\text { Bilingual dictionary } \\
\text { with }\end{array}$ & - & $\sqrt{ }$ & - & - & $\sqrt{ }$ & $\sqrt{ }$ & $\sqrt{ }$ & - & - & 4 & 4.4 \\
\hline & pictures & & & & & & & & & & & \\
\hline \multirow[t]{2}{*}{4} & Multilingual & - & - & - & - & - & - & $\sqrt{ }$ & - & - & 1 & 11.1 \\
\hline & $\begin{array}{l}\text { dictionary with } \\
\text { pictures }\end{array}$ & & & & & - & - & $v$ & - & - & 1 & 11.1 \\
\hline \multirow[t]{2}{*}{5} & $\begin{array}{l}\text { Multilingual } \\
\text { thematic dictionary } \\
\text { with }\end{array}$ & - & - & - & - & - & - & $\sqrt{ }$ & - & - & 1 & 11.1 \\
\hline & pictures & & & & & & & & & & & \\
\hline
\end{tabular}

From Table 3, it can be seen that seven elementary schools $(77.7 \%)$ only have a bilingual dictionary, namely English-Indonesian, and there are pictures on the back of the dictionary. Four schools $(4.44 \%)$ have a bilingual dictionary with pictures, and only one school has a multilingual thematic dictionary with pictures. (Indonesian, English, Chinese). From these findings, it can be concluded that only a very small number of schools have a multilingual dictionary, and even there are no multilingual dictionaries (English, Indonesian, and Balinese).

Regarding the findings above, it is obvious that the schools are lacking in resources, especially dictionaries. Both teachers and students realized the importance of developing their vocabulary, which can be done from dictionaries. Unfortunately, the observation result proved the schools do not have the kinds of dictionaries required. Thus, the researchers found it urgent to provide them with the necessary resources in the form of dictionaries [15], [22]-[26].

\section{CONCLUSION}

The findings and discussion presented above have clearly described that both teachers and students stated the importance of vocabulary in developing literacy. The observations also strengthened that the schools were mostly lacking in the learning facilities and resources, especially dictionaries. The dictionaries referred to in this study were multilingual thematic dictionaries (English, Indonesian, and Balinese) accompanied with colorful pictures to suit the characteristics of young learners. To equip them with suitable sources that match the condition, ease, and flexibility of learning, they also agreed with printed and digital dictionaries. The printed ones were for those with difficult access to technology, while the digital ones were for those with adequate access. With this in mind, the users, in this case, the primary school students, could later on experience and maximize their learning with any relevant sources based on their condition. Thus, the result of this research is a stepping stone for conducting a further study on the development of the required dictionaries. Furthermore, it is recommended that the teachers in primary schools give more access to the use of dictionaries to develop literacy.

\section{AUTHORS' CONTRIBUTIONS}

All authors contributed for the completion of this research. Ni Made Ratminingsih, the main author, was the person in charge of the whole process of research and writing of the article. The co-authors, Ketut Agustini, I Gede Budasi, I Ketut Trika Adi Ana, and Ida Ayu Rathsitha Dewi, were in charge of the library explorations of theoretical and empirical reviews as well as collecting and analyzing data. They also took part in revieweing and editing the article.

\section{REFERENCES}

[1] B. Condliffe et al., Project-based learning: A literature review, in: Mdrc, no. October, 2017, pp. $1-84$. 
[2] FactMaps, "PISA worldwide ranking-average score of math, science, and reading." 2017, [Online]. Available: http://factsmaps.com/pisaworldwide-ranking-average-score-of-mathscience-reading/.

[3] Y. E. Harususilo, "Skor PISA terbaru Indonesia, ini 5 PR besar pendidikan pada era Nadiem Makarim." 2019, [Online]. Available: https://edukasi.kompas.com/read/2019/12/04/1300 2801/skor-pisa-terbaru-indonesia-ini-5-pr-besarpendidikan-pada-era-nadiem-makarim?page=all.

[4] A. Abrori, Improving reading literacy strategy through seven programs of reading interest containing da' wah message, in: Proceedings of J. Islam. Cul. Educ, vol. 3, 2018, pp. 205-225, DOI: 10.18326/attarbiyah.v3i2.205-225.

[5] S. H. Wijayanti, Indonesian students' reading literacy, in: Proceedings of Adv. Soc. Sci. Educ. Hum. Res, vol. 390, 2020, pp. 61-65.

[6] N. M. Ratminingsih, Metode dan strategi pembelajaran bahasa Inggris. Depok, PT. Rajagrafindo Persada, 2017.

[7] N. M. Ratminingsih, I. G. Budasi, Local culturebased picture storybooks for teaching English for young learners, 2018. DOI: $10.1051 /$ shsconf/20184200016.

[8] P. R. Wulandari, N. M. Ratminingsih, and I. G. Budasi, Multilingual thematic picture dictionary: Assisting young learners' literacy Int, in: Proceedings of J. Lang. Lit, vol. 5, 2021, pp. 2030 .

[9] A. Y. Chan, Advanced Cantonese ESL learners' use of a monolingual dictionary for language production Lexikos, in: Lexikos, vol. 22, 2012, pp. 109- 138 .

[10] F. A. Loan, Impact of technology on reading habits: A glimpse on the world literature Nat, in Sem. Role of School Libraries in Quality Education, 2009, pp. 212-218.

[11] H. N. Clair-Thompson, A. Graham, and S. Marsham, Exploring the reading practices of undergraduate students, in: Proceedings of Educ. Inq, vol. 9, 2018, pp. 284-298.

[12] S. Knight, Dictionary use while reading: The effects on comprehension and vocabulary acquisition for students of different verbal abilities, in: Proceedings of Mod. Lang. J, vol. 78, 1994, pp. 285-299.

[13] C. Prichard, Evaluating L2 readers' vocabulary strategies and dictionary use, in: Proceedings of Read. a ForeignLang, vol. 20, 2008, pp. 216-231.
[14] S. A. L. Medina, Effects of reading strategy and dictionary instruction in an undergraduate foreign language reading comprehension group, in: Proceedings of Folio, vol. 50, 2019, pp. 127-138

[15] M. A. Alharb, Using different types ofdictionaries for improving EFL reading comprehension and vocabulary learning The JALT, in: Proceedings of CALL J, vol. 12, 2016, pp. 124-149.

[16] J. Cenoz, Defining multilingualism, in: Proceedings of Ann. Rev. App. Ling, vol. 33, 2013, pp. 3-18.

[17] European Commission, Final report: High level group on multilingualism, Luxembourg, 2007.

[18] E. E. García, Classroom experiences and learning outcomes for dual language learning children: An early childhood agenda for educators and policy makers Dual language learners in the early childhood classroom. Baltimore, MD: Paul H. Brookes, 2011

[19] A. Rogers, Multilingualism in education: The role of first language, in: Proceedings of Ind. J. App.Ling, vol. 4, 2014, pp. 1-9.

[20] L. Osterhout, Second language learning and changes in the brain, in: Proceedings of $\mathrm{J}$. Neuroling, vol. 21, 2008, pp. 509-521.

[21] S. Kemp, We are social media, 2019 https://datareportal.com/reports/digital-2019indonesia.

[22] A. Setyawan, "Pengertian dan jenis-jenis kamus." 2015, [Online]. Available: https://belajarbahasa.id/artikel/dokumen/88pengertian-dan-jenis-jenis-kamus-

[23] I. S. P. Nation, Learning vocabulary in another language, Cambridge, Cambridge UniversityPress, 2001.

[24] S. M. R. Amirian and Z. Heshmatifar, The impact of using digital dictionary on vocabulary learning and retention of Iranian EFL learners, in: Proceedings of Int. J. Res. Stud. Educ. Tech, vol. 2, 2013, pp. 35-44.

[25] M. T. M, N. A, Mobile-assisted language learning, in: Proceedings of Int. J. Distrib. Par. Syst., vol. 3 , 2012, pp.309-319.

[26] J. J. Parsons, D. Oja, Computer concepts 2013. Comprehensive, Boston, MA: Course Technology Cengage Learning, 2013.

[27] J. Li, Needs Analysis: An effective way in business English curriculum design, in: Proceedings of J. Theory Pr. Lang. Stud., vol. 4, 2014. pp. 1869-1874.

[28] S. Menggo, I. M. Suastra, M. Budiarsa, and N. N. Padmadewi, Needs analysis of academic English 
speaking material in promoting 21 st centuryskills, in: Proceedings of Int.J. Instruc, vol. 12, 2019, pp. 739-754.

[29] P. Thiruvengadam, A need for need analysis, in:

Proceedings of Int. J. App.Res. Stud., vol. 2, 2012, pp. 1-6.

[30] T. Hutchinson and A. Waters, English for specific purposes: A learning-centered approach, New York: Cambridge University Press, 1987.

[31] J. W. Creswell, Research design: Qualitative, quantitative and mixed methods approaches, vol. 4, London: Sage publications, 2014. 